\title{
CHST3 wt Allele
}

National Cancer Institute

\section{Source}

National Cancer Institute. CHST3 wt Allele. NCI Thesaurus. Code C116935.

Human CHST 3 wild-type allele is located in the vicinity of $10 \mathrm{q} 22.1$ and is approximately 49 $\mathrm{kb}$ in length. This allele, which encodes carbohydrate sulfotransferase 3 protein, plays a role in the metabolism of proteoglycans. Mutation of the gene is associated with spondyloepiphyseal dysplasia with congenital joint dislocations. 